Article

\title{
High-Efficiency Removal of Cr(VI) from Wastewater by Mg-Loaded Biochars: Adsorption Process and Removal Mechanism
}

\author{
Anyu Li ${ }^{1,2}$, Hua Deng ${ }^{1,2,3, * \mathbb{C} \text {, Yanhong Jiang }}{ }^{1,2}$ and Chenghui Ye ${ }^{1,2}$ \\ 1 Key Laboratory of Ecology of Rare and Endangered Species and Environmental Protection, \\ Ministry of Education, Guangxi Normal University, Guilin 541004, China; lianyu@stu.gxnu.edu.cn (A.L.); \\ jiangjiangyh@sina.com (Y.J.); ye_chenghui@sina.com (C.Y.) \\ 2 Key Laboratory of Ecology of Rare and Endangered Species and Environmental Protection, \\ Guangxi Normal University, Guilin 541004, China \\ 3 School of Environment and Resources, Guangxi Normal University, Guilin 541004, China \\ * Correspondence: denghua@mailbox.gxnu.edu.cn
}

Received: 4 January 2020; Accepted: 17 February 2020; Published: 20 February 2020

\begin{abstract}
Biochars were produced with magnesium chloride as an additive for the sorption of hexavalent chromium dissolved in water using five types of straw (from taro, corn, cassava, Chinese fir, and banana) and one type of shell (Camellia oleifera) as the raw materials. The removal of hexavalent chromium by the six biochars mainly occurred within $60 \mathrm{~min}$ and then gradually stabilized. The kinetics of the adsorption process were second order, the Langmuir model was followed, and the adsorption of $\mathrm{Cr}(\mathrm{VI})$ by the six biochars was characterized by Langmuir monolayer chemisorption on a heterogeneous surface. Banana straw biochar (BSB) had the best performance, which perhaps benefitted from its special structure and best adsorption effect on $\mathrm{Cr}(\mathrm{VI})$, and the theoretical adsorption capacity was calculated as $125.00 \mathrm{mg} / \mathrm{g}$. For the mechanism analysis, $\mathrm{Mg}$-loaded biochars were characterized before and after adsorption by Fourier transform infrared spectroscopy (FTIR), X-ray diffractometry (XRD), and scanning electron microscopy/energy dispersive spectroscopy (SEM-EDS). The adsorption mechanism differed from the adsorption process of conventional magnetic biochar, and biochar interactions with $\mathrm{Cr}(\mathrm{VI})$ were controlled mainly by electrostatic attraction, complexation, and functional group bonding. In summary, the six Mg-loaded biochars exhibit great potential advantages in removing $\mathrm{Cr}(\mathrm{VI})$ from wastewater and have promising potential for practical use, especially BSB, which shows super-high adsorption performance.
\end{abstract}

Keywords: magnesium-loaded biochar; $\mathrm{Cr}(\mathrm{VI})$ removal; removal mechanism; wastewater; sorption

\section{Introduction}

Chromium (Cr) waste is mainly generated by electroplating, leather making, chemical, pigment, metallurgy, refractory, and other industries [1], and in the aqueous environment, $\mathrm{Cr}$ mainly exists as $\mathrm{Cr}(\mathrm{VI})$ and $\mathrm{Cr}(\mathrm{III})$ [2]. Due to the high solubility, toxicity, mutagenicity, carcinogenicity, and teratogenicity of $\mathrm{Cr}(\mathrm{VI})$, it cannot be biodegraded and will accumulate in the food chain, thus causing damage to the human body [3]. $\mathrm{Cr}(\mathrm{VI})$ causes greater biotoxicity and environmental hazards than does $\mathrm{Cr}$ (III) [4]. Thus, the mass concentration of hexavalent $\mathrm{Cr}$ in wastewater must be strictly controlled and wastewater can only be discharged after reaching a standard.

At present, traditional methods for removing $\mathrm{Cr}$ from wastewater mainly include electrolysis [5], chemical methods [6], ion exchange methods [7,8], membrane separation [9], catalytic reduction [10], and adsorption $[11,12]$. The bioavailability, reactivity, and mobility levels of pollutants can be suitably 
controlled by adsorption. Therefore, it is an inevitable trend to study and prepare adsorbents with high adsorption capacities and low costs [13].

Biochar is produced via oxygen-limited pyrolysis from different biomass materials [14] that present carbon contents (achieved by controlling the pyrolysis temperature) as high as $51.60-85.02 \%$ [15] and are rich in acid-base groups, such as carboxyl $(-\mathrm{COOH})$ and phenolic hydroxyl $(-\mathrm{OH})$ groups [16]. Biochar is a new type of adsorbent with excellent adsorption properties for nutrient elements (ammonia nitrogen, phosphorus), organic dyes (Congo red, malachite green, etc.), and heavy metals $(\mathrm{Cd}, \mathrm{Cr}, \mathrm{Cu}$, $\mathrm{Pb}$, etc.) [16]. Therefore, researchers at home and abroad have studied the adsorption performance and mechanisms of biochar. For example, biochar modified with $\mathrm{Fe}_{3} \mathrm{O}_{4} @ \mathrm{SiO}_{2}-\mathrm{NH}_{2}$ particles had a maximum adsorption capacity for hexavalent chromium ions of $27.20 \mathrm{mg} / \mathrm{g}$, and its adsorption mechanism was composed of three steps for $\mathrm{Cr}(\mathrm{VI})$ on magnetic biochar [17]. A sulfuric acid pretreatment was applied, and then a $\mathrm{MgO}$-coated biochar was used to prepare composite materials, which significantly improved the capacity for the adsorption of $\mathrm{Cr}(\mathrm{VI})$. A theoretical maximum adsorption capacity of $62.89 \mathrm{mg} / \mathrm{g}$ was estimated using the Langmuir model. The mechanism study showed that hexavalent chromium was adsorbed by the biochar through chemical interaction with $\mathrm{MgO}$ [18]. A new type of biochar-supported zero-valent iron nanocomposite (biochar-CMC-nZVI) was developed for the removal of hexavalent chromium from water. The adsorption capacity could reach $112.50 \mathrm{mg} / \mathrm{g}$, thus proving that electrostatic attraction, reduction, and surface complexation are the main removal mechanisms. Moreover, this work showed the potential of biochar-CMC-nZVI as an efficient, green, and economical adsorbent for $\mathrm{Cr}(\mathrm{VI})$ [19]. A novel $\mathrm{N}$-doped magnetic biochar was synthesized by the pyrolysis of an agar biomass loaded with ferric chloride. This char had a maximum adsorption capacity of $142.86 \mathrm{mg} / \mathrm{g}$ for hexavalent chromium [20].

In this work, the six starting materials (taro, corn, cassava, Chinese fir, banana, and Camellia oleifera) were loaded with a $\mathrm{MgCl}_{2}$ solution. The objectives were to (1) determine the $\mathrm{Cr}(\mathrm{VI})$ adsorption properties of the biochars obtained from the mentioned starting materials; (2) use various characterization techniques to determine the adsorption mechanisms; and (3) study the redox process of hexavalent chromium in adsorption onto nonmagnetic biochar. The adsorption mechanism was analyzed by a series of characterization methods, such as Fourier transform infrared spectroscopy (FTIR), X-ray diffractometry (XRD), scanning electron microscopy/energy dispersive spectroscopy (SEM-EDS), and XPS, which provided a scientific reference for understanding the effective mechanisms for wastewater treatment and the use of agricultural waste to prepare high-performance biochar. In addition, the pollution and damage of agricultural waste to the environment is very serious; thus, accelerating the process of resource utilization of agricultural waste has far-reaching significance for improving the ecological environment. Moreover, the use of agricultural waste to prepare high-performance adsorbent materials to treat wastewater is consistent with the principle of sustainable green chemistry.

\section{Materials and Methods}

\subsection{Preparation of the Biochars}

The preparation of biochars was achieved using a novel sample preparation method to improve the adsorption capacity of the adsorbent. The six raw biomass materials (taro, corn, cassava, Chinese fir, banana, and Camellia oleifera) all came from farmland near Guangxi Normal University, and the preparation process was the same for all materials. The materials were washed, pressed to eliminate excess water, and dried at $105^{\circ} \mathrm{C}$. Then, the materials were pulverized and passed through a 60-mesh sieve. Ten grams of 60 -mesh biomass raw material was sieved, modified with $1 \mathrm{~mol} / \mathrm{L} \mathrm{MgCl}_{2}$, added to $150 \mathrm{~mL} \mathrm{MgCl}_{2}$, shaken for $1 \mathrm{~h}$, immersed at room temperature for $23 \mathrm{~h}$, filtered, dried for $24 \mathrm{~h}$, and carbonized in a tubular electric furnace at a temperature of $430{ }^{\circ} \mathrm{C}$ for $4 \mathrm{~h}$. Biochars prepared from the six starting materials were labelled as BSB (from banana straw), CSB (from cassava straw), FSB (from Chinese fir straw), MSB (from corn straw), TSB (from taro straw), and CFSB (from Camellia oleifera shell biochar). 


\subsection{Characterization of the Biochars}

The chemical compositions (carbon, hydrogen, nitrogen, and oxygen) of the six biochars were determined by an elemental analyzer (Eurovector, EA-3000, Gütersloh, Italy). The BET method was used for the determination of the surface area, total pore volume and average pore diameter by $\mathrm{N}_{2}$ adsorption (Micromeritics ASAP-2920, Norcross, GA, USA). An X-ray powder diffractometer (BRUKER D8 ADVANCE, Karlsruhe, Germany) was used to characterize the crystallization and chemical composition of the biochars before and after adsorption. SEM was used to observe the surface characteristics of the biochar samples in a field emission environment (Zeiss, EVO-18, Jena, Germany). A FTIR analyzer (Bruker Tensor 27, BRUKER AXS GMBH, Karlsruhe, Germany) was used to determine the functional groups in the biochars. The ultrastructure of the biochar was observed using high-resolution transmission electron microscopy (FEI Tecnai G2 F20, FEI, Portland, OR, USA).

\subsection{Batch Adsorption Experiments}

Samples of each prepared biochar $(20 \mathrm{mg})$ were weighed to a conical flask, to which $50 \mathrm{~mL}$ of a $50 \mathrm{mg} / \mathrm{L}$ potassium dichromate $\left(\mathrm{K}_{2} \mathrm{Cr}_{2} \mathrm{O}_{7}\right)$ solution was added, and the solution was then immediately placed in a constant-temperature oscillator to oscillate at $200 \mathrm{rpm}$. Samples were taken in conical flasks after $0,10,20,40,60,90,120,150,180$, and $240 \mathrm{~min}$, filtered with a $0.45 \mu \mathrm{m}$ microporous membrane, and stored in $10 \mathrm{~mL}$ centrifuge tubes for sample determination. The determination of hexavalent chromium $(\mathrm{Cr}(\mathrm{VI}))$ was realized by the diphenylcarbazide spectrophotometry method. For the adsorption thermodynamics studies, samples of $20 \mathrm{mg}$ of each prepared biochar were weighed into a series of conical flasks, and then $50 \mathrm{~mL}$ of $0.5,1,2,4,6,8,12,24,40$, or $50 \mathrm{mg} / \mathrm{L} \mathrm{K}_{2} \mathrm{Cr}_{2} \mathrm{O}_{7}$ solution was added. The $\mathrm{pH}$ of the adsorption solution was maintained constant, and the flask was removed after shaking at $20^{\circ} \mathrm{C}, 30^{\circ} \mathrm{C}$, and $40^{\circ} \mathrm{C}$ for $4 \mathrm{~h}$ at $200 \mathrm{rpm}$ in a thermostatic oscillator. $\mathrm{Cr}(\mathrm{VI})$ was also determined by the diphenylcarbazide spectrophotometry method.

The adsorption capacities $\mathrm{Q}(\mathrm{mg} / \mathrm{g})$ of the biochars were calculated by Equation (1):

$$
\mathrm{Q}=\left(\mathrm{C}_{0}-\mathrm{C}_{\mathrm{e}}\right) \times \mathrm{V} / \mathrm{m}
$$

where $C_{0}$ is the initial concentration and $C_{e}$ the equilibrium concentration, both in $\mathrm{mg} / \mathrm{L} ; \mathrm{V}$ is the volume $(\mathrm{mL})$, while $\mathrm{m}$ is the weight of the biochar $(\mathrm{g})$.

\subsection{Experiment Testing Regeneration Performance}

The biochar desorption experiment was carried out using a $0.2 \mathrm{~mol} / \mathrm{L}$ aqueous $\mathrm{NaOH}$ solution and a methanol solution as a desorbent. The adsorbed material $(100 \mathrm{mg})$ was washed with a large amount of distilled water to remove unadsorbed $\mathrm{Cr}(\mathrm{VI})$. Then, the adsorbed biochar was vigorously stirred with $100 \mathrm{~mL}$ of $0.2 \mathrm{~mol} / \mathrm{L} \mathrm{NaOH}$ aqueous solution on a magnetic stirrer for $1 \mathrm{~h}$. Finally, the biochar was vigorously stirred with $100 \mathrm{~mL}$ of methanol solution. The regenerated adsorbent was placed in a $50 \mathrm{~mL}, 50 \mathrm{mg} / \mathrm{L} \mathrm{Cr}(\mathrm{VI})$ solution. After adsorption, the concentration of the adsorption solution was measured by the diphenylcarbazide spectrophotometry method, and adsorption and desorption of the biochar were carried out five times.

\section{Results and Discussion}

\subsection{Physical Characteristics}

Table 1 shows the elemental compositions of the biochars. The contents of the biochars prepared from different materials had notable differences, with FSB having the highest carbon content of $64.53 \%$. To study and characterize the basic characteristics of the prepared Mg-loaded modified biochars, HRTEM, and zeta potential analyses were used to analyse the six biochars as shown in Figure 1. The HRTEM results show that the surfaces of the six biochars are covered with spherical or irregular particles, which may be compounds formed by supporting Mg. The particle size statistics were 
analyzed by Image J. The average particle diameters of BSB, FSB, MSB, CFSB, TSB, and CSB were 33.30, 6.44, 9.47, 3.27, 6.70, and $5.46 \mathrm{~nm}$, respectively. The results indicate that the Mg-containing compounds were successfully loaded on the surface of the biochars, providing the possibility of ion exchange and other reactions (including complex precipitation, coordination, functional grouping, etc.). The surface of an adsorbent has a negative charge when $\mathrm{pH}>\mathrm{pH}_{\mathrm{PZC}}$ [21]. When the opposite is true, the surface is positively charged [22]. The values of $\mathrm{pH}$ and $\mathrm{pH}$ PZC can be found in Table 1 . The six biochars in the $\mathrm{Cr}(\mathrm{VI})$-containing solution have $\mathrm{pH}<\mathrm{pH}$ PZC. The surface of the biochar material is positively charged, which is beneficial to the adsorption of $\mathrm{Cr}(\mathrm{VI})$ in the solution (under natural $\mathrm{pH}$, as shown in Table 1); therefore, the charge on the surface is positive. Dichromate $\left(\mathrm{Cr}_{2} \mathrm{O}_{7}{ }^{2-}\right)$ in the solution can be electrostatically attracted [23] to biochar with a positive surface charge to promote the adsorption capability of $\mathrm{Cr}_{2} \mathrm{O}_{7}{ }^{2-}$. According to the complete set of mesoporous data, the surface areas and total pore volumes of the biochars before adsorption are smaller than those after adsorption, although the initial average aperture is greater than that after adsorption, thereby proving that biochar can effectively adsorb $\mathrm{Cr}_{2} \mathrm{O}_{7}{ }^{2-}$, which enters the pores of the biochar. We tested the contents of acid-base groups on the surfaces of the six biochars before and after adsorption by the Boehm titration method (Table 1). The contents of acid-base functional groups after adsorption all decreased. The comparison shows that the decrease in acid functional groups was greater than that in the basic functional groups, thus indicating that the contribution of the acid functional groups to the adsorption of $\mathrm{Cr}_{2} \mathrm{O}_{7}{ }^{2-}$ was greater than that of the basic functional groups [24].
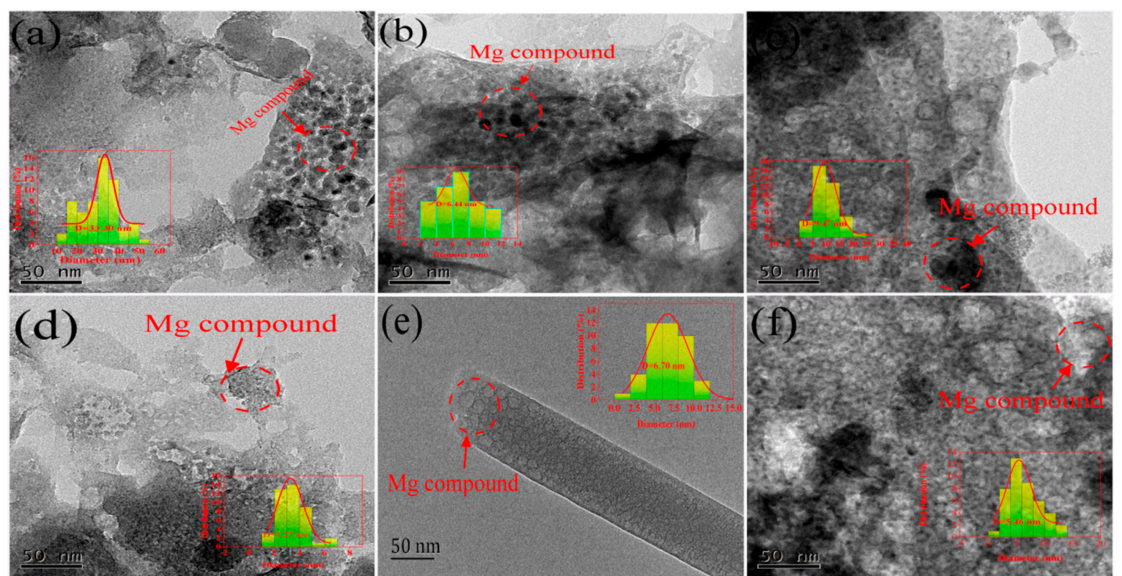

Figure 1. HRTEM images of six different Mg-loaded biochars. $(\mathbf{a} ; \mathbf{b} ; \mathbf{c} ; \mathbf{d} ; \mathbf{e}$; and $\mathbf{f}$ represent BSB, FSB, MSB, CFSB, TSB, and CSB, respectively). 
Table 1. Basic characteristics of the biochars from six different raw materials.

\begin{tabular}{|c|c|c|c|c|c|c|c|}
\hline Index & & BSB & CSB & FSB & MSB & TSB & CFSB \\
\hline $\mathrm{pH}$ & & 7.21 & 6.68 & 7.88 & 8.44 & 7.53 & 7.21 \\
\hline $\mathrm{pH}$ & & 10.31 & 10.54 & 8.92 & 9.38 & 10.11 & 9.77 \\
\hline Biochar magnesium content $(\mathrm{g} / \mathrm{kg})$ & before & 190.62 & 113.21 & 75.09 & 65.95 & 181.95 & 98.20 \\
\hline \multirow{2}{*}{$\operatorname{BET}\left(\mathrm{m}^{2} / \mathrm{g}\right)$} & before & 16.6839 & 10.3278 & 2.5272 & 9.3057 & 5.4411 & 4.3860 \\
\hline & after & 36.3582 & 32.1380 & 27.6502 & 57.1085 & 33.6400 & 53.9261 \\
\hline \multirow{2}{*}{ Total pore volume $\left(\mathrm{cm}^{3} / \mathrm{g}\right)$} & before & 0.0267 & 0.0406 & 0.0037 & 0.0263 & 0.0098 & 0.0114 \\
\hline & after & 0.0900 & 0.0579 & 0.0408 & 0.0706 & 0.0446 & 0.0775 \\
\hline \multirow{2}{*}{ Average aperture (nm) } & before & 15.99 & 15.71 & 7.41 & 13.01 & 9.60 & 10.47 \\
\hline & after & 9.91 & 7.22 & 5.91 & 4.95 & 5.31 & 5.76 \\
\hline \multirow{2}{*}{ Before adsorption } & (1) $(\mathrm{mmol} / \mathrm{g})$ & 1.1789 & 1.1181 & 0.7037 & 1.0300 & 1.1069 & 0.8729 \\
\hline & (2) $(\mathrm{mmol} / \mathrm{g})$ & 1.1238 & 1.1216 & 1.1241 & 1.1168 & 1.1240 & 1.1192 \\
\hline \multirow{2}{*}{ After adsorption } & (1) $(\mathrm{mmol} / \mathrm{g})$ & 0.8523 & 0.8523 & 0.5193 & 0.6738 & 0.5688 & 0.4607 \\
\hline & (2) $(\mathrm{mmol} / \mathrm{g})$ & 1.1189 & 1.0565 & 1.0325 & 0.7457 & 1.0565 & 1.0085 \\
\hline \multirow{4}{*}{ Mass composition } & $\mathrm{C}(\%)$ & 34.66 & 47.13 & 64.53 & 48.98 & 44.73 & 34.73 \\
\hline & $\mathrm{H}(\%)$ & 4.81 & 7.81 & 3.31 & 2.96 & 1.86 & 1.86 \\
\hline & N (\%) & 0.85 & 0.66 & 0.14 & 1.42 & 1.69 & 1.69 \\
\hline & $\mathrm{O}(\%)$ & 20.31 & 22.41 & 26.05 & 23.48 & 21.22 & 20.89 \\
\hline
\end{tabular}

Note: (1): represents acidic oxygen-containing functional groups; and (2): represents alkaline oxygen-containing functional groups. 


\subsection{Possible Mechanisms for Cr(VI) Adsorption onto the Biochars}

\subsubsection{FTIR}

The FTIR results before and after treatment with the $\mathrm{Cr}(\mathrm{VI})$ solutions for the six biochars are provided in Figure 2. All biochars showed similar trends in the spectrograms and had similar functional groups [16]: - $\mathrm{OH}\left(3429,3430,3427,3431\right.$, and $\left.3417 \mathrm{~cm}^{-1}\right),-(\mathrm{OH})_{2}$-substituted aromatic rings or anthraquinones $\left(1623,1641,1651,1621,1622\right.$, and $\left.1630 \mathrm{~cm}^{-1}\right)$, phenolic hydroxyl $(1055,1060$, $1047,1048,1088$, and $\left.1039 \mathrm{~cm}^{-1}\right)$, and phenols $\left(610,631,622,612,614\right.$, and $\left.608 \mathrm{~cm}^{-1}\right)$. These groups are responsible for the binding of hexavalent chromium onto the six biochars, such as CSB [25]. The FTIR spectra before and after adsorption show important changes. The positions of $-\mathrm{OH}$ and $-(\mathrm{OH})_{2}$-substituted anthraquinones or aromatic rings shift after adsorption and the peak widths' decrease, which may provide evidence for hydrogen bonding during the process of adsorption [26]. Furthermore, the absorption peaks at $1039-1088 \mathrm{~cm}^{-1}$ and $608-631 \mathrm{~cm}^{-1}$ are not noticeable, suggesting that these groups present in biochar may be related to the $\mathrm{Cr}(\mathrm{VI})$ reduction [27].
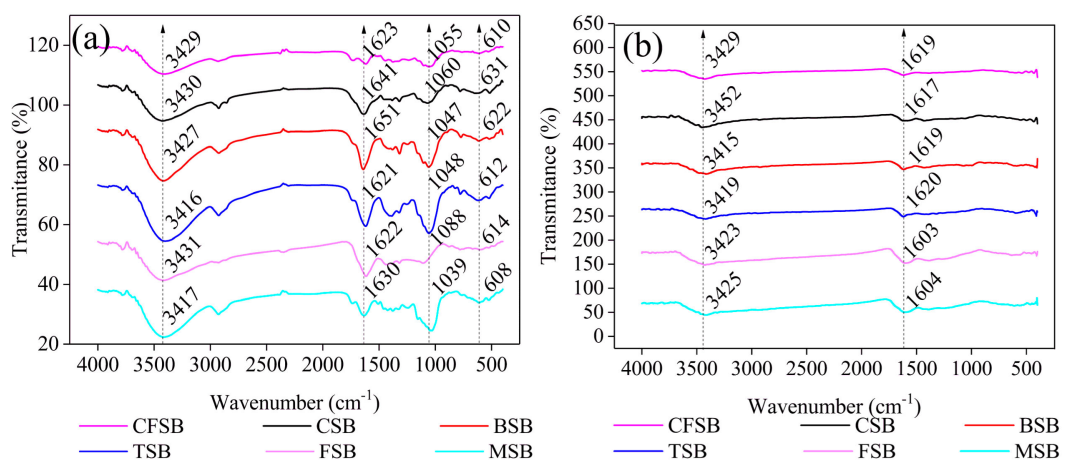

Figure 2. FTIR spectra of the six different biochars (a) before and (b) after adsorption of $\mathrm{Cr}(\mathrm{VI})$.

\subsubsection{SEM/EDS}

The SEM/EDS analysis was conducted before and after the adsorption of hexavalent chromium onto the biochars as shown in Figure 3. According to the SEM/EDS results of the six biochars before adsorption, the biochar itself has a suitable pore structure and a rough and convex surface, which is a prerequisite for adsorption [28]. Moreover, the figure shows that $\mathrm{Mg}$ ions in the six types of biochars almost covered the biochar surface, thus indicating the successful preparation of Mg-modified biochar. In addition, the elemental distribution map after adsorption shows that the biochar surface after reaction is covered with $\mathrm{Mg}, \mathrm{O}$, and $\mathrm{Cr}$ elements as background materials, thereby indicating that $\mathrm{Mg} / \mathrm{Cr}$ compounds are uniformly deposited on the surface [24]. 


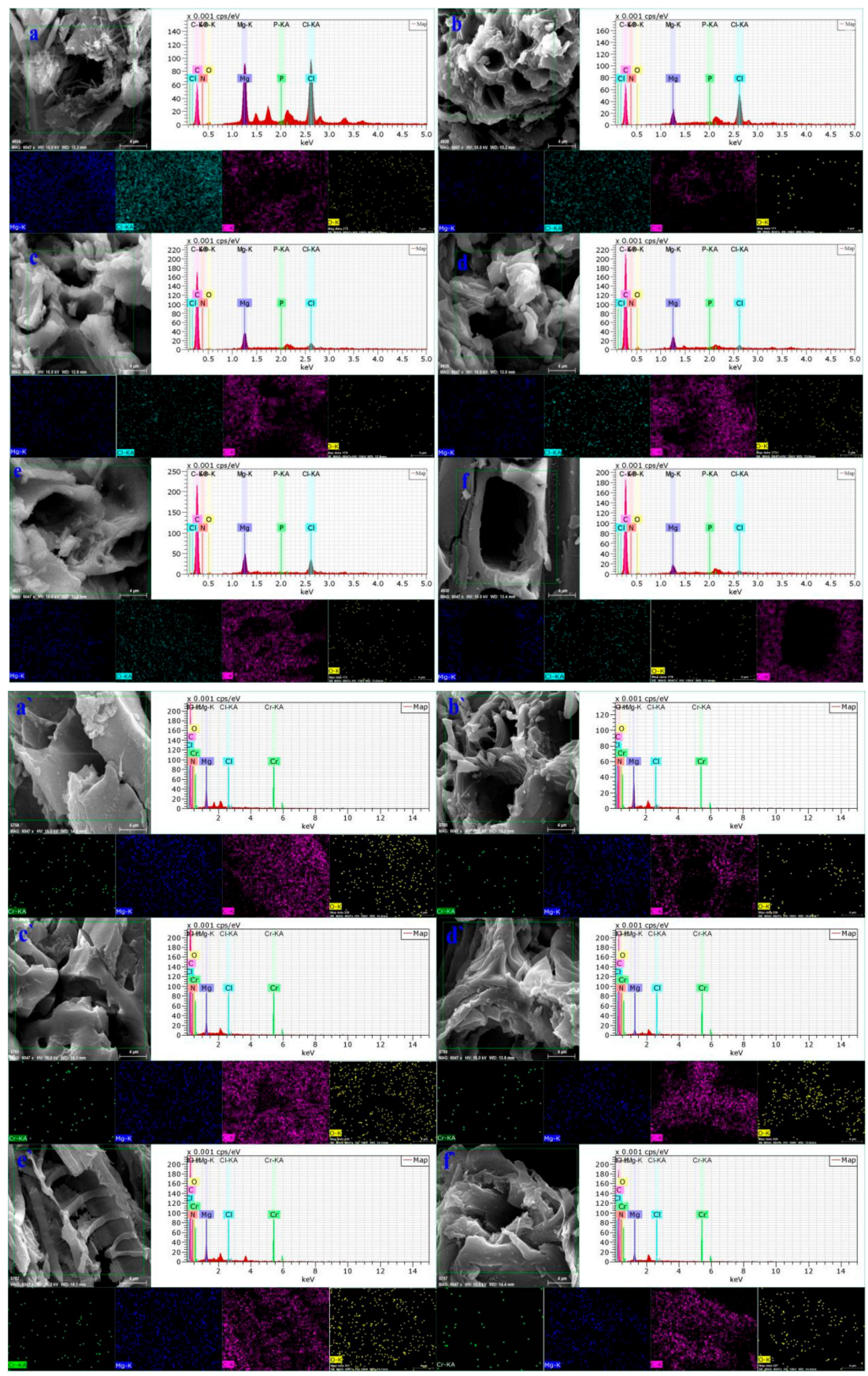

Figure 3. Scanning electron microscopic images of the six biochars. $\mathbf{a}, \mathbf{a}^{\prime} ; \mathbf{b}, \mathbf{b}^{\prime} ; \mathbf{c}, \mathbf{c}^{\prime} ; \mathbf{d}, \mathbf{d}^{\prime} ; \mathbf{e}, \mathbf{e}^{\prime} ;$ and $\mathbf{f}, \mathbf{f}^{\prime}$ represent before and after $\mathrm{Cr}(\mathrm{VI})$ adsorption on BSB, CSB, MSB, CFSB, TSB, and FSB, respectively.

\subsubsection{XRD}

The XRD patterns before and after the adsorption of $\mathrm{Cr}(\mathrm{VI})$ onto the six biochars, such as BSB, are shown in Figure 4. The biochar before adsorption was searched by the jade 5.0 phase and compared with the JCPDS card. The existence of $\mathrm{Mg}_{2}(\mathrm{OH})_{3} \mathrm{Cl} \cdot 4 \mathrm{H}_{2} \mathrm{O}$ (PDF card 07-0412) is confirmed in BSB, CSB, and TSB at $\mathrm{d}=8.17,7.14,5.99,4.07,3.87$, and 2.46, thus indicating that $\mathrm{Mg}_{2}(\mathrm{OH})_{3} \mathrm{Cl} \cdot 4 \mathrm{H}_{2} \mathrm{O}$ is the main magnesium-carrying phase of the three biochars. $\mathrm{MgSO}_{3} \cdot 3 \mathrm{H}_{2} \mathrm{O}$ (PDF card 51-0530) exists in MSB at $\mathrm{d}=6.70,3.35$, and 2.62, showing that $\mathrm{MgSO}_{3} \cdot 3 \mathrm{H}_{2} \mathrm{O}$ is the main crystalline phase of the magnesium-charged MSB. $\mathrm{Mg}_{4} \mathrm{Al}(\mathrm{OH})_{12} \mathrm{CO}_{3} \cdot 3 \mathrm{H}_{2} \mathrm{O}$ (PDF card 51-1528) exists in FSB at $\mathrm{d}=7.61$ and 3.78, which indicates that $\mathrm{Mg}_{4} \mathrm{Al}(\mathrm{OH})_{12} \mathrm{CO}_{3} \cdot 3 \mathrm{H}_{2} \mathrm{O}$ is the main crystalline phase of the magnesium-charged FSB. MgO (PDF card 65-0476) exists in CFSB at $d=2.11$ and 1.49, which 
indicates that the magnesium-charged CFSB has $\mathrm{MgO}$ as the main crystalline phase. The results of the magnesium treatment show that other compounds may be used to load the magnesium-modified biochar. According to the XRD patterns after adsorption, CFSB, CSB, TSB, FSB, and MSB mainly occur in the form of $\mathrm{MgCrO}_{4} \cdot 7 \mathrm{H}_{2} \mathrm{O}$ (PDF card 01-0243), while BSB mainly occurs in the form of $\mathrm{Cr}(\mathrm{OH})_{3}$ (PDF card 12-0241). By combining these results with the kinetics results, it is shown that complexation precipitation is the main form of removing $\mathrm{Cr}$ from solutions [29].
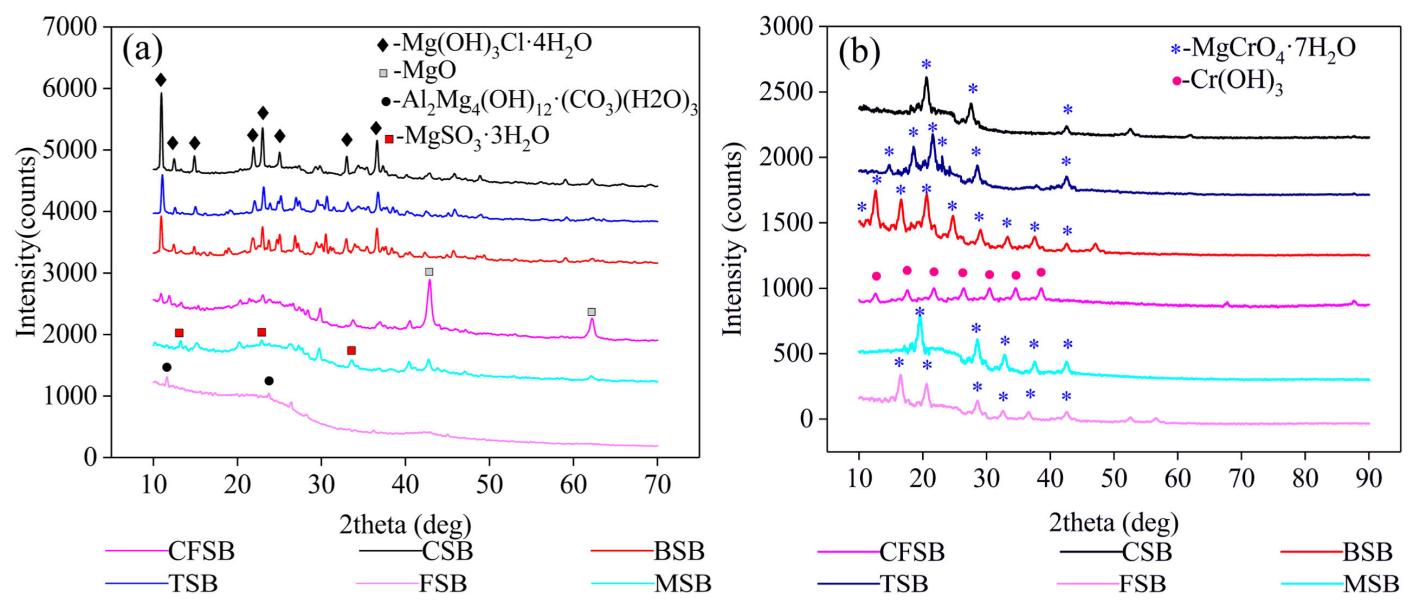

Figure 4. XRD analysis of the six biochars (a) before and (b) after adsorption of $\mathrm{Cr}(\mathrm{VI})$.

\subsection{Effect of the Solution $p H$}

During the adsorption of $\mathrm{Cr}(\mathrm{VI})$ by biochar, the initial $\mathrm{pH}$ of the solution affects the surface charge distribution of the biochar, as shown in Figure 5. The six biochars follow similar laws. With increase in $\mathrm{pH}$ value, adsorption amount first exhibits a rising trend but then falls with continuing increase. This shows that $\mathrm{pH}$ value has a great influence on the adsorption performance of $\mathrm{Cr}(\mathrm{VI})$. The optimal $\mathrm{pH}$ value of the adsorption liquid is found to be 2, with the adsorption capacities of BSB, CSB, TSB, FSB, CFSB, and MSB being 112.26, 70.47, 45.78, 16.13, 18.15, and $38.38 \mathrm{mg} / \mathrm{g}$, respectively. With a low $\mathrm{pH}$ solution $(\mathrm{pH}=1-3)$, there is a large amount of $\mathrm{H}^{+}$ions in the solution, which alters the surface charge, ionization degree, surface structure and ion morphology of the adsorption materials. Simultaneously, $\mathrm{Cr}(\mathrm{VI})$ mainly exists in the form of $\mathrm{HCrO}_{4}{ }^{-}$, which can combine with adsorbent to form a more stable compound that is beneficial to the adsorption of $\mathrm{Cr}(\mathrm{VI})$ by biochar. However, experiments show that adsorption capacity with a $\mathrm{pH}$ of 2 is higher than that with a $\mathrm{pH}$ of 1 , which may be because the introduction of an excessive amount of $\mathrm{H}^{+}$may destroy some functional groups on the biochar surface, leading to a decrease in adsorption capacity. Specifically, when the $\mathrm{pH}$ of the solution increases, functional groups on the surface of the biochar (such as $-\mathrm{OH},-\mathrm{COOH}$, etc.) undergo proton dissociation to produce negatively charged functional groups. Furthermore, at high $\mathrm{pH}, \mathrm{HCrO}_{4}{ }^{-}$can also dissociate to form $\mathrm{CrO}_{4}{ }^{2-}$ and $\mathrm{H}^{+}$, which are not conducive to the adsorption of $\mathrm{Cr}(\mathrm{VI})$. Because the chromium reduction method is primarily used for chromium-containing industrial wastewater (especially electroplating wastewater), under acidic conditions ( $\mathrm{pH}$ of approximately 2), the reducing agent (ferrous sulfate, sodium sulfite, etc.) is first added to $\mathrm{Cr}(\mathrm{VI})$ to obtain $\mathrm{Cr}(\mathrm{III})$, and then lime, sodium hydroxide, etc. are added to adjust the $\mathrm{pH}$ to form $\mathrm{Cr}(\mathrm{OH})_{3}$ precipitate. In this study, according to the actual wastewater treatment process, the $\mathrm{pH}$ of the solution was adjusted to approximately 2, and the functional groups contained in the biochar reduced some $\mathrm{Cr}(\mathrm{VI})$ to form a precipitate. 


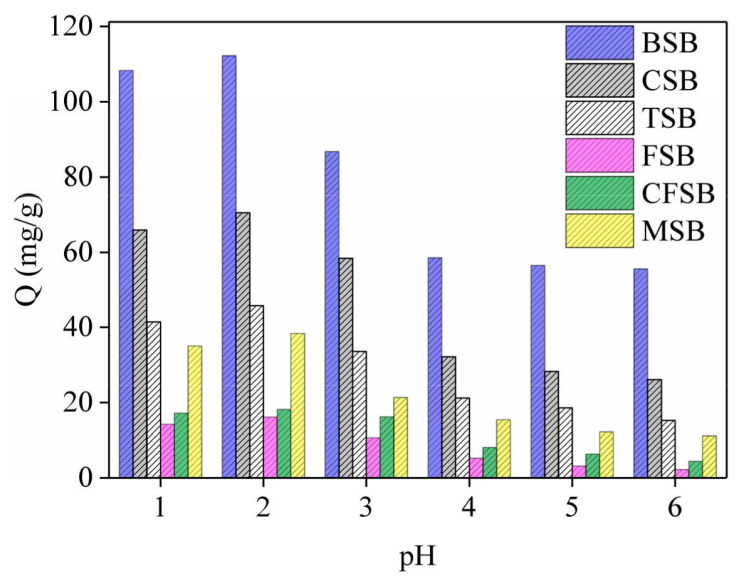

Figure 5. Effect of adsorption on $\mathrm{Cr}(\mathrm{VI})$ at different $\mathrm{pH}$ values.

\subsection{Adsorption Study}

\subsubsection{Adsorption Kinetics Study}

Adsorption kinetics are an important indicator of adsorption process design and operation control. They determine the adsorption rates of adsorbents for pollutants and ultimately determine the adsorption rates of adsorbents [30]. The adsorption fitting curves of the six biochars for $\mathrm{Cr}(\mathrm{VI})$ are shown in Figure 6. The prophase removal rate of $\mathrm{Cr}(\mathrm{VI})$ by TSB and CSB is faster than that of the other biochars. After adsorption for $20 \mathrm{~min}$, the adsorption amount reaches $65.95 \%$ and $58.70 \%$ of the saturated adsorption amount, and with an increase in adsorption time, the adsorption amount continues to increase. The rising rates of TSB and CSB decrease after $90 \mathrm{~min}$ and $60 \mathrm{~min}$, respectively, and the adsorption amounts reach $90.00 \%$ and $89.19 \%$ of the equilibrium adsorption amount, respectively, gradually reaching equilibrium. Additionally, the adsorption rates of TSB and CSB were calculated according to the pseudo-second-order kinetic equation and are $0.0995 \mathrm{mg} /(\mathrm{g} \cdot \mathrm{min})$ and $0.4154 \mathrm{mg} /(\mathrm{g} \cdot \mathrm{min})$, respectively, indicating that CSB has faster adsorption rates. BSB has the best adsorption capacity for $\mathrm{Cr}(\mathrm{VI})$. When the adsorption initially begins, the adsorption amount reaches $61.89 \mathrm{mg} / \mathrm{g}$, with the process possibly benefitting from the large specific surface area of BSB (as shown in Table 1). FSB and CFSB have poor adsorption capacities for $\mathrm{Cr}(\mathrm{VI})$, reaching adsorption equilibrium at $150 \mathrm{~min}$ and $120 \mathrm{~min}$, respectively. The adsorption of MSB is slow. After $5 \mathrm{~min}$, the adsorption amount only reaches $9.97 \%$ of the saturated adsorption amount. Within $150 \mathrm{~min}$, the adsorption amount increases steadily with increasing adsorption time, and adsorption equilibrium is reached at $180 \mathrm{~min}$. Over the adsorption time, the adsorption sites on the surface of the biochar are gradually occupied by chromium ions, resulting in the occurrence of adsorption equilibrium. The curve in Figure 6a shows that the six biochars show a significant increase in the adsorption rate at the beginning of the adsorption and then slowly reach adsorption equilibrium, which is the phenomenon of "first fast and then slow" [15,31]. 

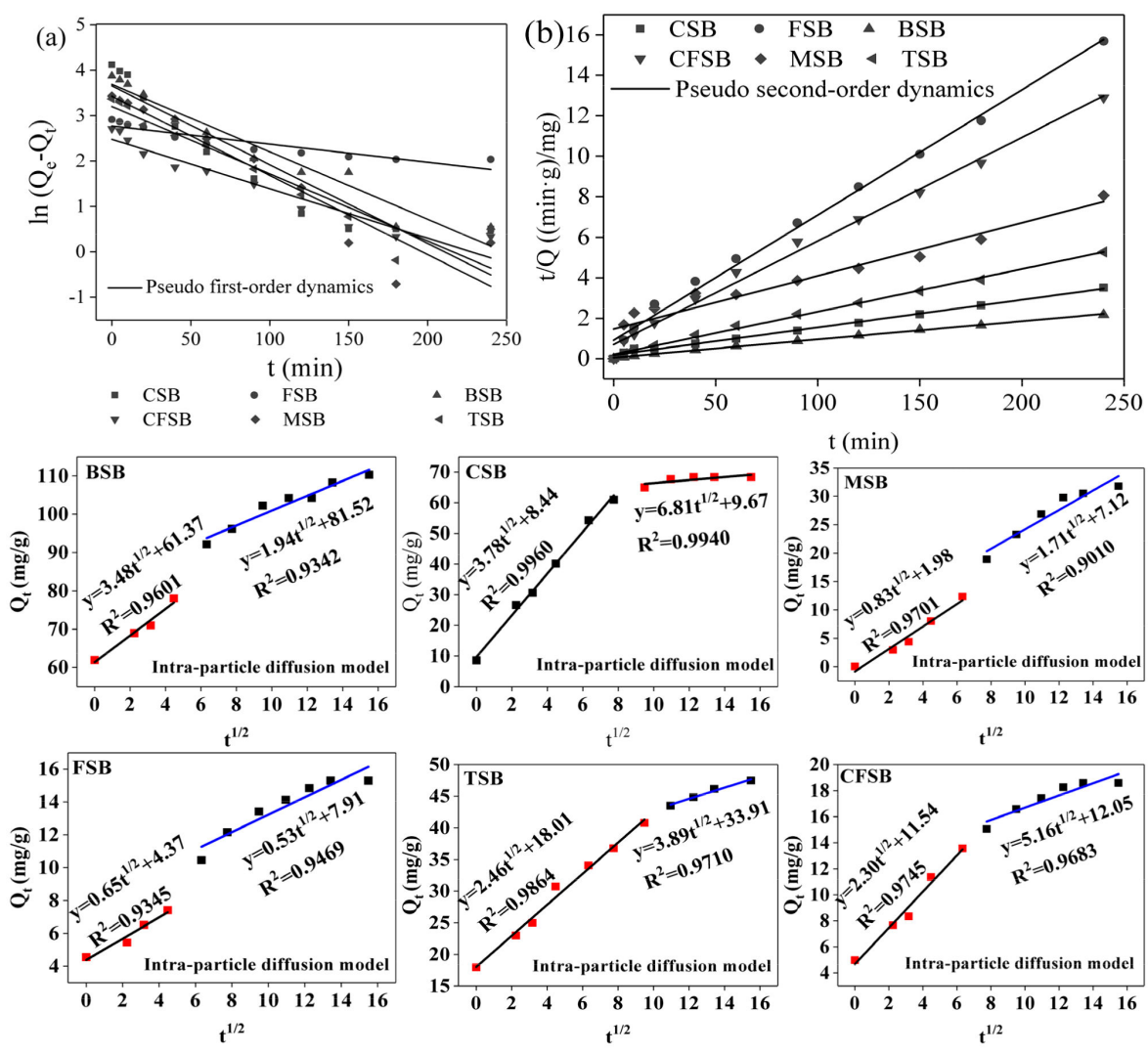

Figure 6. Adsorption kinetic curves of $\mathrm{Cr}(\mathrm{VI})$ on the six biochars ((a): Pseudo first-order dynamics fitting curve; (b): Pseudo second-order dynamics fitting curve).

The adsorption mechanism was analyzed using pseudo-first-order equations, pseudo-second-order equations and the intraparticle diffusion model. The equations for the models are as follows $[13,16]$ :

Pseudo-first-order kinetic equation:

$$
\ln \left(Q_{e}-Q_{t}\right)=\ln Q_{e}-K_{1} \times t
$$

Pseudo-second-order kinetic equation:

$$
\mathrm{t} / \mathrm{Q}_{\mathrm{t}}=1 / \mathrm{K}_{2} \mathrm{Q}_{\mathrm{e}}{ }^{2}+\mathrm{t} / \mathrm{Q}_{\mathrm{t}}
$$

Internal diffusion equation for particles:

$$
\mathrm{Q}_{t}=\mathrm{K}_{3} \mathrm{t}^{1 / 2}+\mathrm{C},
$$

Adsorption rate:

$$
\mathrm{h}=\mathrm{K}_{2} \times \mathrm{Q}_{\mathrm{e}}^{2}
$$

where $Q_{t}(\mathrm{mg} / \mathrm{g})$ is the fraction of $\mathrm{Cr}(\mathrm{VI})$ adsorbed at time $\mathrm{t}$; $\mathrm{Q}_{\mathrm{e}}(\mathrm{mg} / \mathrm{g})$ is the fraction of $\mathrm{Cr}$ adsorbed at equilibrium; $\mathrm{K}_{1}(1 / \mathrm{min})$ is the pseudo-first-order rate constant; $\left.\mathrm{K}_{2}(\mathrm{~g} / \mathrm{mg} \cdot \mathrm{min})\right)$ is the pseudo-second-order rate constant; and $K_{3}\left(\mathrm{mg} /\left(\mathrm{g} \cdot \mathrm{min}^{0.5}\right)\right)$ is the intraparticle diffusion rate constant. The values of these constants can be found by plotting $\ln \left(Q_{e}-Q_{t}\right)$ versus $t$ and $t / Q_{t}$ versus $t$; respectively. The constant $C$ is related to the border effect. When the mechanism is intraparticle diffusion, $Q_{t}$ and $t^{1 / 2}$ are linearly related, and the straight line passes through the origin. $\mathrm{h}$ is the initial adsorption rate of the material, $\mathrm{mg} /(\mathrm{g} \cdot \mathrm{min})$

The fitting parameters determined using pseudo-first-order kinetics and pseudo-second-order kinetics equations are shown in Table 2. The equilibrium concentration and experimental 
value calculated from the pseudo-first-order kinetics equation are known, the difference is large, and the correlation coefficient $\left(R^{2}\right)$ is relatively small, indicating that the pseudo-first-order kinetic equation is not suitable for describing the adsorption of $\mathrm{Cr}(\mathrm{VI})$ by the six biochars, such as BSB. The pseudo-second-order kinetics equation can well fit the adsorption process of $\mathrm{Cr}(\mathrm{VI})$ by the six biochars, and the fitted $\mathrm{R}^{2}$ is larger (all greater than 0.99), including the values for CFSB, FSB, TSB, MSB, CSB, and BSB. The theoretical adsorption amounts $(19.53,16.16,47.37,38.17,73.53$, and $111.11 \mathrm{mg} / \mathrm{g}$, respectively) are close to the experimental values $(20.24,16.14,31.80,37.58,68.34$, and $110.20 \mathrm{mg} / \mathrm{g}$, respectively), indicating that the adsorption of $\mathrm{Cr}(\mathrm{VI})$ by the six biochars in the experiment is more in line with the pseudo-second-order kinetics equation. At the same time, the pseudo-first-order kinetics equation is only suitable for describing the kinetics model of the initial stage of adsorption. The pseudo-second-order kinetics equation can describe all the stages of the adsorption reaction, including liquid film diffusion, surface adsorption, and internal diffusion. The diffusion process truly reflects the process of adsorption of $\mathrm{Cr}(\mathrm{VI})$ by biochar [32]. Based on the intraparticle diffusion model, it can be seen from Figure 6 that the six kinds of biochar fit two linear graphs, which indicates that the process of $\mathrm{Cr}(\mathrm{VI})$ adsorption is mainly divided into two steps. First, biochar was rapidly adsorbed on the surface. Subsequently, the adsorbate $(\mathrm{Cr}(\mathrm{VI}))$ diffused into the pores on the inner surface of the biochar. This pattern shows that the process is controlled by external mass transfer and then by intra-particle diffusion mass transfer [33]; when $\mathrm{Cr}(\mathrm{VI})$ diffuses into the adsorbent, the diffusion resistance gradually increases, resulting in a decrease in diffusion speed and eventually an adsorption equilibrium state. 
Table 2. Adsorption kinetics parameters for the six types of biochars.

\begin{tabular}{|c|c|c|c|c|c|c|c|c|c|c|c|c|c|c|}
\hline \multirow{2}{*}{\multicolumn{2}{|c|}{ Samples }} & \multicolumn{3}{|c|}{ Pseudo First-order Kinetics } & \multicolumn{3}{|c|}{ Pseudo Second-order Kinetics } & \multirow[b]{2}{*}{$\begin{array}{c}\mathrm{C}_{1} \\
(\mathrm{mg} / \mathrm{g})\end{array}$} & \multicolumn{5}{|c|}{ Intra-particle Diffusion } & \multirow[b]{2}{*}{$\begin{array}{c}Q_{t}^{(1)} \\
(\mathrm{mg} / \mathrm{g})\end{array}$} \\
\hline & & $\begin{array}{c}\mathrm{Q}_{\mathrm{e}} \\
(\mathrm{mg} / \mathrm{g})\end{array}$ & $\begin{array}{c}\mathrm{K}_{1} \\
(1 / \mathrm{min}) \\
\end{array}$ & $\mathbf{R}^{2}$ & $\begin{array}{c}Q_{e} \\
(\mathrm{mg} / \mathrm{g})\end{array}$ & $\begin{array}{c}\mathrm{K}_{2} \\
(\mathrm{~g} / \mathrm{mg} \cdot \mathrm{min})\end{array}$ & $\mathbf{R}^{2}$ & & $\begin{array}{c}\mathrm{K}_{\mathrm{d} 1} \\
\left(\mathrm{mg} /\left(\mathrm{g} \cdot \mathrm{min}^{0.5}\right)\right.\end{array}$ & $\mathbf{R}^{2}$ & $\begin{array}{c}\mathrm{C}_{2} \\
(\mathrm{mg} / \mathrm{g})\end{array}$ & $\begin{array}{c}\mathrm{K}_{\mathrm{d} 2} \\
\left(\mathrm{mg} /\left(\mathrm{g} \cdot \min ^{0.5}\right)\right. \\
\end{array}$ & $\mathbf{R}^{2}$ & \\
\hline CFSB & $\mathrm{Cr}(\mathrm{VI})$ & 11.91 & 0.0109 & 0.9324 & 19.53 & 0.0038 & 0.9936 & 11.54 & 2.30 & 0.9745 & 12.05 & 5.16 & 0.9683 & 20.24 \\
\hline FSB & $\mathrm{Cr}(\mathrm{VI})$ & 15.94 & 0.0040 & 0.8612 & 16.16 & 0.0042 & 0.9933 & 4.37 & 0.65 & 0.9345 & 7.91 & 0.53 & 0.9469 & 16.14 \\
\hline TSB & $\mathrm{Cr}(\mathrm{VI})$ & 24.55 & 0.01148 & 0.9179 & 47.39 & 0.0021 & 0.9961 & 18.0 .1 & 2.46 & 0.9864 & 33.91 & 3.89 & 0.9710 & 31.80 \\
\hline MSB & $\mathrm{Cr}(\mathrm{VI})$ & 30.78 & 0.0174 & 0.8920 & 38.17 & 0.0015 & 0.9262 & 1.98 & 0.83 & 0.9701 & 7.12 & 1.71 & 0.9010 & 37.58 \\
\hline CSB & $\mathrm{Cr}(\mathrm{VI})$ & 38.59 & 0.1730 & 0.8715 & 73.53 & 0.0055 & 0.9940 & 8.44 & 3.78 & 0.9960 & 9.67 & 6.81 & 0.9940 & 68.34 \\
\hline BSB & $\mathrm{Cr}(\mathrm{VI})$ & 38.90 & 0.0148 & 0.9497 & 111.11 & 0.0015 & 0.9984 & 61.37 & 3.48 & 0.9601 & 81.52 & 1.94 & 0.9342 & 110.20 \\
\hline
\end{tabular}

(1) Actual amount of adsorption. 


\subsubsection{Adsorption Isotherm Study}

The amount of biochar adsorbed increases as the adsorption concentration increases and finally reaches the adsorption equilibrium. The fitting was performed using the equations of the Freundlich and Langmuir models to elucidate the mechanism of the process and calculate the theoretical saturated adsorption capacity of biochar on $\mathrm{Cr}(\mathrm{VI})$.

Langmuir model:

$$
\mathrm{Qe}=\mathrm{CeQm} /\left(\mathrm{K}_{\mathrm{L}}+\mathrm{Ce}\right)
$$

Freundlich model

$$
\mathrm{Qe}=\mathrm{K}_{\mathrm{F}} \mathrm{Ce}^{1 / \mathrm{n}}
$$

where $\mathrm{Q}_{\mathrm{m}}(\mathrm{mg} / \mathrm{g})$ is the maximum absorption capacity; $\mathrm{Q}_{\mathrm{e}}(\mathrm{mg} / \mathrm{g})$ is the fraction of $\mathrm{Cr}(\mathrm{VI})$ adsorbed; $\mathrm{C}_{\mathrm{e}}$ $(\mathrm{mg} / \mathrm{L})$ is the equilibrium concentration of $\mathrm{Cr}(\mathrm{VI}) ; \mathrm{C}_{0}(\mathrm{mg} / \mathrm{L})$ is the initial $\mathrm{Cr}(\mathrm{VI})$ concentration; $\mathrm{K}_{\mathrm{L}}$ is the affinity constant; $\mathrm{K}_{\mathrm{F}}$ is the Freundlich constant; and $1 / \mathrm{n}$ is the component factor (dimensionless).

The effectiveness of the adsorbent is expressed by the separation factor $R_{L}$,

$$
\mathrm{R}_{\mathrm{L}}=1 /\left(1+\mathrm{C}_{0} \mathrm{~K}_{\mathrm{L}}\right)
$$

This equation shows how the initial concentration $C_{0}$ influences the adsorption. Here, $R_{L}=0$ is irreversible adsorption; $\mathrm{R}_{\mathrm{L}}=1$ is linear adsorption; $0<\mathrm{R}_{\mathrm{L}}<1$ is effective adsorption; and $\mathrm{R}_{\mathrm{L}}>1$ is disadvantageous adsorption.

The corresponding Gibbs free energy $\left(\Delta G^{0}\right)$ can be determined using $K_{L}$ calculated via the Langmuir model at different temperatures, and then the van't Hoff equation is used to calculate the enthalpy changes $\left(\Delta \mathrm{H}^{0}\right)$ and entropy change $\left(\Delta \mathrm{S}^{0}\right)$ as

$$
\begin{gathered}
\Delta \mathrm{G}^{0}=-\mathrm{RT} \ln \left(\rho \mathrm{K}_{\mathrm{D}}\right) \\
\ln \left(\rho \mathrm{K}_{\mathrm{D}}\right) \frac{\Delta \mathrm{S}^{0}}{\mathrm{R}}-\frac{\Delta \mathrm{H}^{0}}{\mathrm{RT}}
\end{gathered}
$$

In the formula, the Gibbs free energy units are $\mathrm{kJ} / \mathrm{mol}$, the units of the enthalpy change are $\mathrm{J} /(\mathrm{mol} \cdot \mathrm{K})$, and the units of entropy re $\mathrm{kJ} / \mathrm{mol}$; $\rho$ is the density of water, $10^{6} \mathrm{mg} / \mathrm{L} ; \mathrm{R}$ is the gas constant, $8.314 \mathrm{~J} /(\mathrm{mol} \cdot \mathrm{K})$; $\mathrm{T}$ is the thermodynamic temperature, $\mathrm{K}$.

The adsorption isotherms of the six biochars for $\mathrm{Cr}(\mathrm{VI})$ are shown in Figure 7 . The different biochars displayed increasing amounts of adsorption as the concentration of $\mathrm{Cr}(\mathrm{VI})$ increased. At low concentrations, the adsorption amount of $\mathrm{Cr}(\mathrm{VI})$ increased almost linearly, and at high concentrations, the adsorption amount increased slowly and gradually became stable [19], achieving adsorption equilibrium. The appearance of this law can be explained by the fact that when the $\mathrm{Cr}(\mathrm{VI})$ solution is at a low concentration, the biochar can provide a large number of adsorption sites and acid-base functional groups (such as hydroxyl groups, phenolic hydroxyl groups, and aromatic hydrocarbons), thereby increasing the concentration of the adsorption solution and the adsorption capacity of biochar on $\mathrm{Cr}(\mathrm{VI})$. The adsorption capacities of the six types of biochars, such as CSB, increased with increasing adsorption temperature, indicating that increasing the adsorption temperature within a certain range is beneficial to the adsorption. 

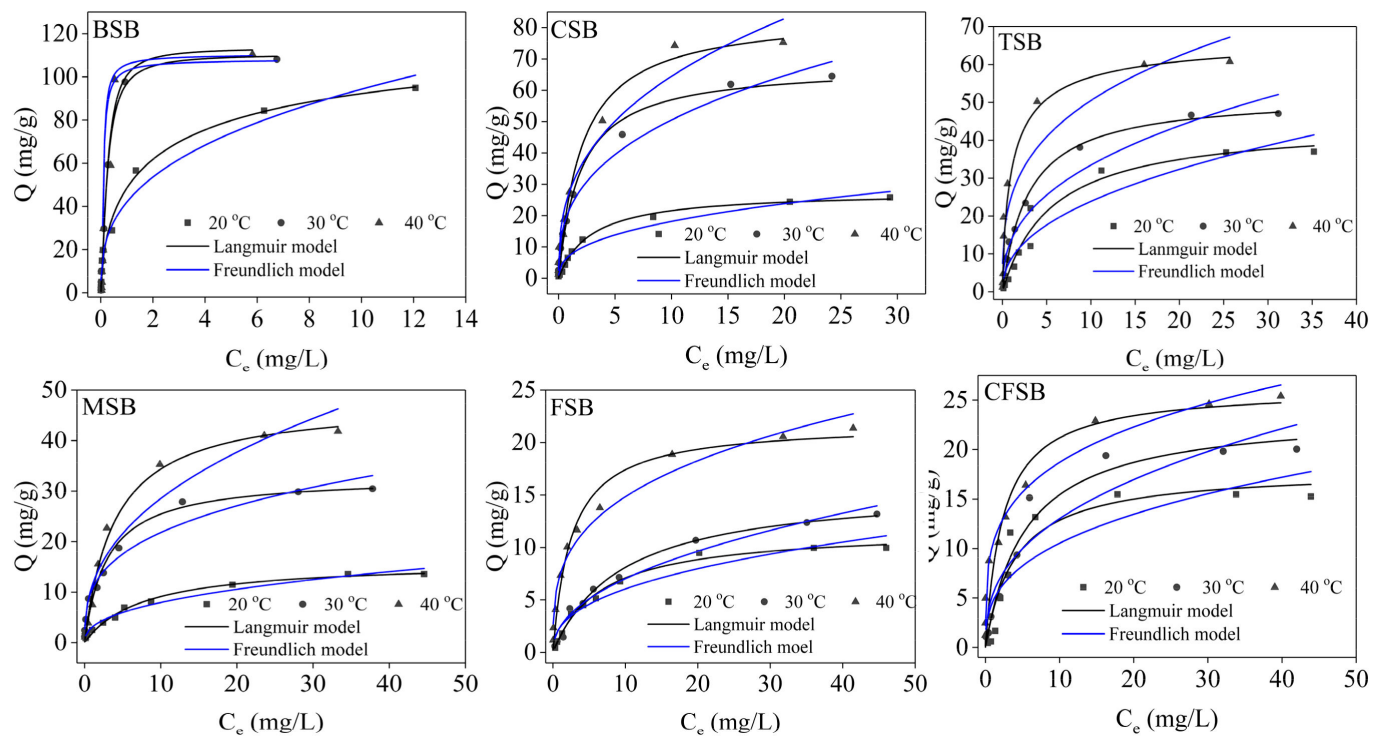

Figure 7. Adsorption isotherms of $\mathrm{Cr}(\mathrm{VI})$ for six different biochars.

The experimental data were fitted using the Langmuir model and the Freundlich model. The adsorption isotherm fitting parameters are shown in Table 3. For the six biochars, the $\mathrm{R}^{2}$ values obtained by the Langmuir model at different temperatures were higher than the $R^{2}$ values calculated by the Freundlich model and the theoretical saturated adsorption amount obtained by the Langmuir model was close to the experimental value. Therefore, the relationships of the six biochars with $\mathrm{Cr}(\mathrm{VI})$ in the experiment are more in line with the Langmuir model [34], indicating that the adsorption process is approximately the adsorption of monolayers. If the $\mathrm{R}_{\mathrm{L}}$ value is in the range of $0-1$, then the $R_{L}$ values of all the biochars are less than 1 , indicating that the adsorption of $\mathrm{Cr}(\mathrm{VI})$ by the biochars is beneficial adsorption $[35,36]$. The calculated thermodynamic parameters of adsorption are shown in Table 4 . It can be seen from Table 4 that the $\Delta G^{0}$ values of the six biochars are all less than 0 , indicating that adsorption occurs spontaneously. As the temperature increases, $\Delta G^{0}$ decreases, indicating that an increase in temperature is conducive to adsorption. The $\Delta \mathrm{H}^{0}$ and $\Delta \mathrm{S}^{0}$ values of the six biochars were all greater than 0 , providing further evidence that the increase in temperature promoted adsorption. At the same time, we compared the adsorption capacity of six kinds of biochar without Mg loading. The theoretical saturated adsorption capacities of BSB, CFSB, TSB, CSB, FSB, and MSB were calculated by the Langmuir model to be $84.75,12.92,36.90,47.17,12.52$, and $16.08 \mathrm{mg} / \mathrm{g}$, respectively. A comparison of the Mg-modified biochar shows that the adsorption amount of $\mathrm{Cr}(\mathrm{VI})$ by the biochar after modification is remarkably improved (see Supplementary Materials Figure S1 and Table S2). Upon comparing the adsorption capacities for $\mathrm{Cr}(\mathrm{VI})$ of different biochars, the $\mathrm{Cr}(\mathrm{VI})$ adsorption amount achieved by BSB at $40^{\circ} \mathrm{C}$ was the highest at up to $125.00 \mathrm{mg} / \mathrm{g}$, indicating that BSB has great potential for use as a strong adsorbent. The experimental material removed phosphorus more efficiently than other tested materials (see Supplementary Materials Table S1). 
Table 3. Adsorption parameters of the isotherm models for $\mathrm{Cr}(\mathrm{VI})$ for the six different biochars.

\begin{tabular}{|c|c|c|c|c|c|c|c|c|c|}
\hline \multirow{2}{*}{\multicolumn{3}{|c|}{$\begin{array}{c}\text { Samples } \\
\text { T/K }\end{array}$}} & \multicolumn{4}{|c|}{ Langmuir } & \multicolumn{3}{|c|}{ Freundlich } \\
\hline & & & $Q_{m}(\mathrm{mg} / \mathrm{g})$ & $\mathrm{K}_{\mathrm{L}}(\mathrm{L} / \mathrm{mg})$ & $\mathbf{R}^{2}$ & $\mathbf{R}_{\mathbf{L}}$ & $1 / n$ & $K_{F}(g /(m g \cdot h))$ & $\mathbf{R}^{2}$ \\
\hline \multirow{3}{*}{ CSB } & \multirow{3}{*}{$\mathrm{Cr}(\mathrm{VI})$} & 293 & 27.85 & 0.37 & 0.9910 & $0.0513-0.8438$ & 0.5087 & 1.59 & 0.9415 \\
\hline & & 303 & 66.67 & 0.86 & 0.9908 & $0.0227-0.6993$ & 0.4104 & 17.82 & 0.9786 \\
\hline & & 313 & 78.13 & 1.06 & 0.9836 & $0.0185-0.6535$ & 0.3881 & 22.18 & 0.9343 \\
\hline \multirow{3}{*}{ FSB } & \multirow{3}{*}{$\mathrm{Cr}(\mathrm{VI})$} & 293 & 11.68 & 0.08 & 0.9950 & $0.2000-0.9615$ & 0.6482 & 1.43 & 0.9214 \\
\hline & & 303 & 15.77 & 0.11 & 0.9812 & $0.1538-0.9748$ & 0.6204 & 1.61 & 0.9607 \\
\hline & & 313 & 22.03 & 0.50 & 0.9951 & $0.0385-0.8123$ & 0.3967 & 6.12 & 0.9648 \\
\hline \multirow{3}{*}{ BSB } & \multirow{3}{*}{$\mathrm{Cr}(\mathrm{VI})$} & 293 & 96.15 & 2.04 & 0.9936 & $0.0097-0.4950$ & 0.5104 & 3.70 & 0.9276 \\
\hline & & 303 & 114.94 & 2.86 & 0.9955 & $0.0069-0.4115$ & 0.4498 & 4.33 & 0.8635 \\
\hline & & 313 & 125.00 & 3.70 & 0.9394 & $0.0054-0.3509$ & 0.3680 & 4.39 & 0.8021 \\
\hline \multirow{3}{*}{ CFSB } & \multirow{3}{*}{$\mathrm{Cr}(\mathrm{VI})$} & 293 & 19.84 & 0.10 & 0.8465 & $0.1667-0.9524$ & 0.7503 & 1.75 & 0.7869 \\
\hline & & 303 & 22.57 & 0.22 & 0.9854 & $0.0833-0.9009$ & 0.5118 & 3.87 & 0.9382 \\
\hline & & 313 & 25.84 & 0.75 & 0.9935 & $0.0259-0.7220$ & 0.2774 & 10.03 & 0.9539 \\
\hline \multirow{3}{*}{ MSB } & \multirow{3}{*}{$\mathrm{Cr}(\mathrm{VI})$} & 293 & 15.22 & 0.18 & 0.9855 & $0.1000-0.9174$ & 0.5084 & 2.54 & 0.9114 \\
\hline & & 303 & 31.65 & 0.58 & 0.9935 & $0.0333-0.7752$ & 0.3972 & 9.04 & 0.9781 \\
\hline & & 313 & 47.18 & 0.68 & 0.9933 & $0.0286-0.7463$ & 0.2026 & 20.61 & 0.9497 \\
\hline \multirow{3}{*}{ TSB } & \multirow{3}{*}{$\mathrm{Cr}(\mathrm{VI})$} & 293 & 45.25 & 0.15 & 0.9798 & $0.1176-0.9302$ & 0.6882 & 5.04 & 0.9352 \\
\hline & & 303 & 52.36 & 0.32 & 0.9986 & $0.0588-0.3472$ & 0.6111 & 9.22 & 0.9192 \\
\hline & & 313 & 63.29 & 1.05 & 0.9960 & $0.0187-0.6557$ & 0.4930 & 19.83 & 0.8086 \\
\hline
\end{tabular}


Table 4. Endothermic thermodynamic parameters of $\mathrm{Cr}(\mathrm{VI})$ by biochar

\begin{tabular}{|c|c|c|c|c|c|}
\hline \multirow{2}{*}{ Biochars } & \multicolumn{3}{|c|}{$\Delta \mathrm{G}^{0}(\mathrm{KJ} / \mathrm{mol})$} & \multirow{2}{*}{$\Delta \mathrm{H}^{0}(\mathrm{KJ} / \mathrm{mol})$} & \multirow{2}{*}{$\Delta S^{0}(\mathrm{~J} /(\mathrm{mol} \cdot \mathrm{K}))$} \\
\hline & $293 \mathrm{~K}$ & $303 \mathrm{~K}$ & $313 \mathrm{~K}$ & & \\
\hline CSB & -31.23 & -34.42 & -36.10 & 40.28 & 244.86 \\
\hline FSB & -27.50 & -29.24 & -34.15 & 69.24 & 328.51 \\
\hline BSB & -35.39 & -37.45 & -39.36 & 22.90 & 199.04 \\
\hline CFSB & -28.05 & -30.99 & -35.20 & 76.79 & 357.12 \\
\hline MSB & -29.48 & -33.43 & -34.95 & 51.11 & 276.32 \\
\hline TSB & -29.03 & -31.93 & -36.08 & 73.75 & 350.13 \\
\hline
\end{tabular}

\subsection{Cyclic Performance of Mg-Loaded Biochars}

The recycling performance of the adsorbent is indispensable in the actual application process. The cyclic adsorption performance of the six modified biochars is studied by using $0.2 \mathrm{~mol} / \mathrm{L}$ of a $\mathrm{NaOH}$ solution and methanol solution as the de-washing agent. As shown in Figure 8, the adsorption capacities of the six biochars TSB, CFSB, MSB, BSB, CSB, and FSB after five rounds of cyclic adsorption accounted for $76.79 \%, 64.41 \%, 81.07 \%, 80.00 \%, 75.25 \%$, and $62.59 \%$ of the initial adsorption amount, respectively. BSB and MSB exhibited excellent recyclability. The evidence shows that biochar prepared from different types of magnesium biomass supported by magnesium chloride has stable adsorption performance in $\mathrm{Cr}(\mathrm{VI})$ solution.
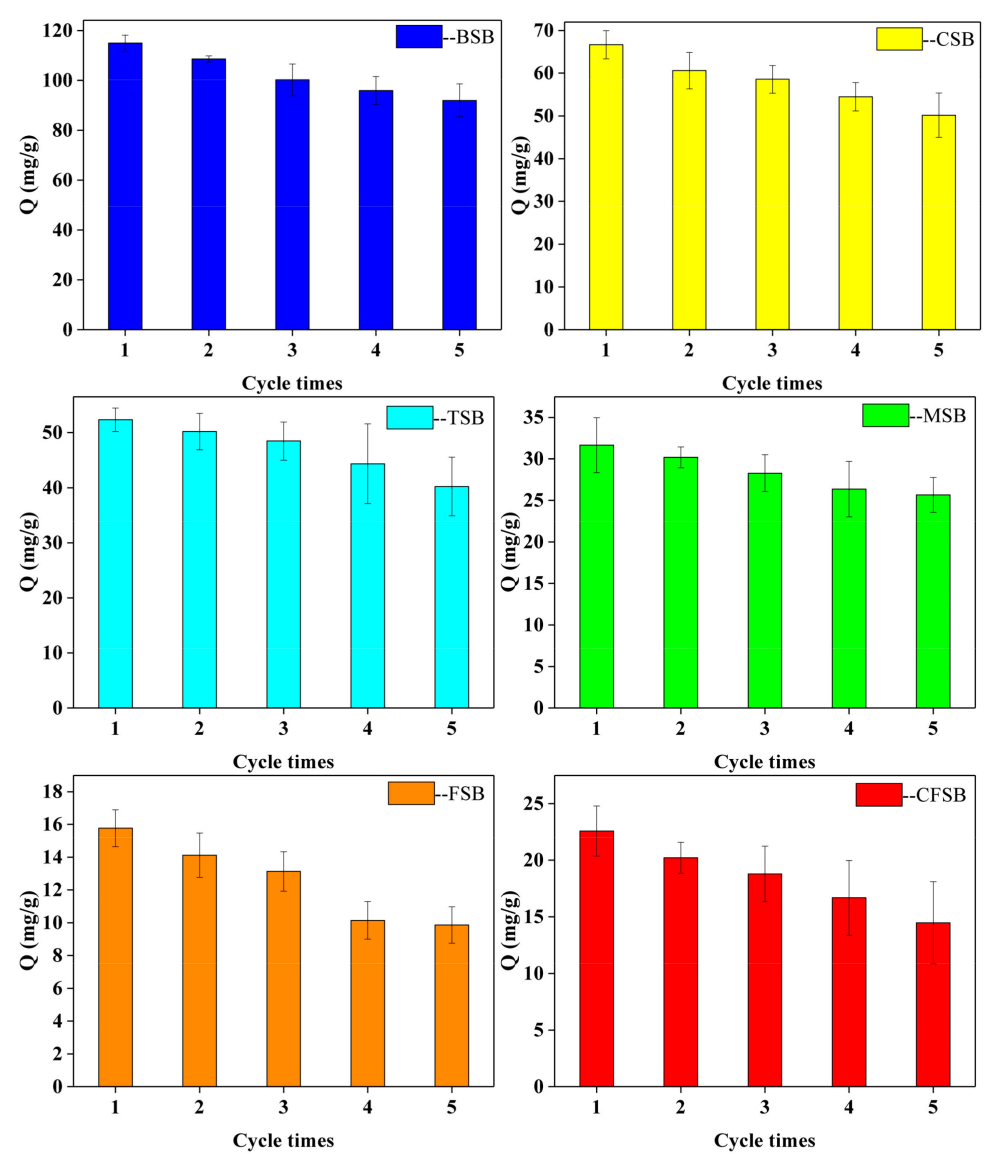

Figure 8. Recycle adsorption performance in wastewater of $\mathrm{Cr}(\mathrm{VI})$ adsorption by $\mathrm{Mg}$-loaded biochars.

\section{Conclusions}

In this work, six different $\mathrm{Mg}$-loaded biochars were prepared to remove $\mathrm{Cr}(\mathrm{VI})$ from water. The prepared materials had magnesium-loaded compounds $\left(\mathrm{Mg}_{2}(\mathrm{OH})_{3} \mathrm{Cl} \cdot 4 \mathrm{H}_{2} \mathrm{O}\right.$ and $\mathrm{MgO}$ particles $)$ 
and showed good capacities as adsorbents. BSB, CSB, TSB, FSB, CFSB, and MSB had the highest adsorption capacity at $\mathrm{pH} 2$ at 114.64, 75.56, 50.21, 17.21, 20.21, and $40.12 \mathrm{mg} / \mathrm{g}$, respectively. The adsorption thermodynamics of the six biochars could be explained by the Langmuir model and were pseudo-second order, and among them, BSB had an ultra-high adsorption capacity of up to $125.00 \mathrm{mg} / \mathrm{g}$. Moreover, the FTIR, SEM/EDS, and XRD analyses indicated that the $\mathrm{Cr}$ adsorption occurred together with reduction, electrostatic attraction, functional group bonding, and complexation. Thus, Mg-loaded biochars could be considered applicable for the removal of $\mathrm{Cr}$ from wastewaters. In summary, this method of synthesizing Mg-loaded biochar offers new opportunities for finding effective and economical treatments to remove $\mathrm{Cr}(\mathrm{VI})$ and other heavy metal contaminants from wastewater.

Supplementary Materials: The following are available online at http://www.mdpi.com/1996-1944/13/4/947/s1. Figure S1: Adsorption of Cr(VI) by six kinds of biochar without Mg loading, Table S1: Comparison of different adsorbents, Table S2: Adsorption thermodynamic fitting parameters.

Author Contributions: Conceptualization, A.L.; methodology, A.L.; software, A.L.; validation, all; formal analysis, A.L. and C.Y.; investigation, A.L.; resources, H.D.; data curation, A.L.; writing一original draft preparation, A.L.; writing-review and editing, A.L.; supervision, H.D.; project administration, H.D.; funding acquisition, H.D. and Y.J. All authors have read and agreed to the published version of the manuscript.

Funding: This work was partially supported by the National Natural Science Foundation of China (no. 41301343), the University Key Laboratory of Karst Ecology and Environmental Change of Guangxi Province (Guangxi Normal University) (YRHJ15Z009), and Supported by Key Laboratory of Ecology of Rare and Endangered Species and Environmental Protection (Guangxi Normal University), Ministry of Education, China (ERESEP2019Z07).

Acknowledgments: We thank AJE (American Journal Experts) for its linguistic assistance during the preparation of this manuscript.

Conflicts of Interest: The authors declare no conflicts of interest.

\section{References}

1. Fan, Z.; Zhang, Q.; Gao, B.; Li, M.; Liu, C.; Qiu, Y. Removal of hexavalent chromium by biochar supported nZVI composite: Batch and fixed-bed column evaluations, mechanisms, and secondary contamination prevention. Chemosphere 2019, 217, 85-94. [CrossRef]

2. Pechova, A.; Pavlata, L. Chromium as an essential nutrient: A review. Vet. Med. 2007, 52, 1-18. [CrossRef]

3. Huang, D.; Liu, C.; Zhang, C.; Deng, R.; Wang, R.; Xue, W.; Luo, H.; Zeng, G.; Zhang, Q.; Guo, X. Cr(VI) removal from aqueous solution using biochar modified with $\mathrm{Mg} / \mathrm{Al}$-layered double hydroxide intercalated with ethylenediaminetetraacetic acid. Bioresour. Technol. 2019, 276, 127-132. [CrossRef] [PubMed]

4. Wang, C.; Gu, L.; Liu, X.; Zhang, X.; Cao, L.; Hu, X. Sorption behavior of Cr(VI) on pineapple-peel-derived biochar and the influence of coexisting pyrene. Int. Biodeterior. Biodegrad. 2016, 111, 78-84. [CrossRef]

5. Ren, L.; Dong, J.; Chi, Z.; Huang, H. Reduced graphene oxide-nano zero value iron (rGO-nZVI) micro-electrolysis accelerating Cr(VI) removal in aquifer. J. Environ. Sci. 2018, 73, 96-106. [CrossRef]

6. Campos, A.F.C.; de Oliveira, H.A.L.; da Silva, F.N.; da Silva, F.G.; Coppola, P.; Aquino, R.; Mezzi, A.; Depeyrot, J. Core-shell bimagnetic nanoadsorbents for hexavalent chromium removal from aqueous solutions. J. Hazard. Mater. 2019, 362, 82-91. [CrossRef]

7. Chao, H.P.; Wang, Y.C.; Tran, H.N. Removal of hexavalent chromium from groundwater by Mg/Al-layered double hydroxides using characteristics of in-situ synthesis. Environ. Pollut. 2018, 243, 620-629. [CrossRef]

8. Godinho, D.; Dias, D.; Bernardo, M.; Lapa, N.; Fonseca, I.; Lopes, H.; Pinto, F. Adding value to gasification and co-pyrolysis chars as removal agents of $\mathrm{Cr}^{3+}$. J. Hazard. Mater. 2017, 321, 173-182. [CrossRef]

9. Du, X.D.; Yi, X.H.; Wang, P.; Zheng, W.; Deng, J.; Wang, C.C. Robust photocatalytic reduction of Cr(VI) on UiO-66-NH2(Zr/Hf) metal-organic framework membrane under sunlight irradiation. Chem. Eng. J. 2019, 356, 393-399. [CrossRef]

10. Li, D.; Li, J.; Jin, Q.; Ren, Z.; Sun, Y.; Zhang, R.; Zhai, Y.; Liu, Y. Photocatalytic reduction of Cr (VI) on nano-sized red phosphorus under visible light irradiation. J. Colloid Interface Sci. 2019, 537, $256-261$. [CrossRef]

11. Kong, Q.; Wei, J.; Hu, Y.; Wei, C. Fabrication of terminal amino hyperbranched polymer modified graphene oxide and its prominent adsorption performance towards Cr(VI). J. Hazard. Mater. 2019, 363, 161-169. [CrossRef] [PubMed] 
12. Wen, Z.; Zhang, Y.; Cheng, G.; Wang, Y.; Chen, R. Simultaneous removal of As(V)/Cr(VI) and acid orange 7 (AO7) by nanosized ordered magnetic mesoporous Fe-Ce bimetal oxides: Behavior and mechanism. Chemosphere 2019, 218, 1002-1013. [CrossRef] [PubMed]

13. Wang, X.; Li, C.; Li, Z.; Yu, G.; Wang, Y. Effect of pyrolysis temperature on characteristics, chemical speciation and risk evaluation of heavy metals in biochar derived from textile dyeing sludge. Ecotoxicol. Environ. Saf. 2019, 168, 45-52. [CrossRef]

14. Yang, X.; Ng, W.; Wong, B.S.E.; Baeg, G.H.; Wang, C.H.; Ok, Y.S. Characterization and ecotoxicological investigation of biochar produced via slow pyrolysis: Effect of feedstock composition and pyrolysis conditions. J. Hazard. Mater. 2019, 365, 178-185. [CrossRef]

15. Ocampo-Perez, R.; Padilla-Ortega, E.; Medellin-Castillo, N.A.; Coronado-Oyarvide, P.; Aguilar-Madera, C.G.; Segovia-Sandoval, S.J.; Flores-Ramírez, R.; Parra-Marfil, A. Synthesis of biochar from chili seeds and its application to remove ibuprofen from water. Equilibrium and 3D modelling. Sci. Total Environ. 2019, 655, 1397-1408. [CrossRef]

16. Jiang, Y.H.; Li, A.Y.; Deng, H.; Ye, C.H.; Wu, Y.Q.; Linmu, Y.D.; Hang, H.L. Characteristics of nitrogen and phosphorus adsorption by Mg-loaded biochar from different feedstocks. Bioresour. Technol. 2019, 276, 183-189. [CrossRef]

17. Shi, S.; Yang, J.; Liang, S.; Li, M.; Gan, Q.; Xiao, K.; Hu, J. Enhanced Cr(VI) removal from acidic solutions using biochar modified by $\mathrm{Fe}_{3} \mathrm{O}_{4} @ \mathrm{SiO}_{2}-\mathrm{NH}_{2}$ particles. Sci. Total. Environ. 2018, 628, 499-508. [CrossRef]

18. Xiao, R.; Wang, J.J.; Li, R.; Park, J.; Meng, Y.; Zhou, B.; Pensky, S.; Zhang, Z. Enhanced sorption of hexavalent chromium $[\mathrm{Cr}(\mathrm{VI})]$ from aqueous solutions by diluted sulfuric acid-assisted $\mathrm{MgO}$-coated biochar composite. Chemosphere 2018, 208, 408-416. [CrossRef]

19. Zhang, S.; Lyu, H.; Tang, J.; Song, B.; Zhen, M.; Liu, X. A novel biochar supported CMC stabilized nano zero-valent iron composite for hexavalent chromium removal from water. Chemosphere 2019, 217, 686-694. [CrossRef]

20. Mian, M.M.; Liu, G.; Yousaf, B.; Fu, B.; Ullah, H.; Ali, M.U.; Abbas, Q.; Mujtaba Munir, M.A.; Ruijia, L. Simultaneous functionalization and magnetization of biochar via NH3 ambiance pyrolysis for efficient removal of $\mathrm{Cr}(\mathrm{VI})$. Chemosphere 2018, 208, 712-721. [CrossRef]

21. Liu, Y.; Sohi, S.P.; Liu, S.; Guan, J.; Zhou, J.; Chen, J. Adsorption and reductive degradation of Cr(VI) and TCE by a simply synthesized zero valent iron magnetic biochar. J. Environ. Manag. 2019, 235, 276-281. [CrossRef] [PubMed]

22. Ding, Z.; Xu, X.; Phan, T.; Hu, X.; Nie, G. High adsorption performance for As(III) and As(V) onto novel aluminum-enriched biochar derived from abandoned Tetra Paks. Chemosphere 2018, 208, 800-807. [CrossRef] [PubMed]

23. An, Q.; Li, X.Q.; Nan, H.Y.; Yu, Y.; Jiang, J.N. The potential adsorption mechanism of the biochars with different modification processes to $\mathrm{Cr}(\mathrm{VI})$. Environ. Sci. Pollut. Res. 2018, 25, 31346-31357. [CrossRef]

24. Wu, B.; Peng, D.; Hou, S.; Tang, B.; Wang, C.; Xu, H. Dynamic study of Cr(VI) removal performance and mechanism from water using multilayer material coated nanoscale zerovalent iron. Environ. Pollut. 2018, 240, 717-724. [CrossRef] [PubMed]

25. Shi, Y.; Zhang, T.; Ren, H.; Kruse, A.; Cui, R. Polyethylene imine modified hydrochar adsorption for chromium (VI) and nickel (II) removal from aqueous solution. Bioresour. Technol. 2018, 247, 370-379. [CrossRef] [PubMed]

26. Xu, J.; Yin, Y.; Tan, Z.; Wang, B.; Guo, X.; Li, X.; Liu, J. Enhanced removal of Cr(VI) by biochar with Fe as electron shuttles. J. Environ. Sci. 2019, 78, 109-117. [CrossRef]

27. Choudhary, B.; Paul, D.; Singh, A.; Gupta, T. Removal of hexavalent chromium upon interaction with biochar under acidic conditions: Mechanistic insights and application. Environ. Sci. Pollut. Res. 2017, 24, 16786-16797. [CrossRef]

28. Abdel-Fattah, T.M.; Mahmoud, M.E.; Ahmed, S.B.; Huff, M.D.; Lee, J.W.; Kumar, S. Biochar from woody biomass for removing metal contaminants and carbon sequestration. J. Ind. Eng. Chem. 2015, 22, 103-109. [CrossRef]

29. Pan, J.J.; Jiang, J.; Xu, R.k. Removal of $\mathrm{Cr}(\mathrm{VI})$ from aqueous solutions by $\mathrm{Na}_{2} \mathrm{SO}_{3} / \mathrm{FeSO}_{4}$ combined with peanut straw biochar. Chemosphere 2014, 101, 71-76. [CrossRef] 
30. Sun, Y.; Yu, I.K.M.; Tsang, D.C.W.; Cao, X.; Lin, D.; Wang, L.; Graham, N.J.D.; Alessi, D.S.; Komárek, M.; Ok, Y.S.; et al. Multifunctional iron-biochar composites for the removal of potentially toxic elements, inherent cations, and hetero-chloride from hydraulic fracturing wastewater. Environ. Int. 2019, 124, 521-532. [CrossRef]

31. Ma, Y.; Liu, W.J.; Zhang, N.; Li, Y.S.; Jiang, H.; Sheng, G.P. Polyethylenimine modified biochar adsorbent for hexavalent chromium removal from the aqueous solution. Bioresour. Technol. 2014, 169, 403-408. [CrossRef] [PubMed]

32. Wu, J.; Zheng, H.; Zhang, F.; Zeng, R.J.; Xing, B. Iron-carbon composite from carbonization of iron-crosslinked sodium alginate for $\mathrm{Cr}(\mathrm{VI})$ removal. Chem. Eng. J. 2019, 362, 21-29. [CrossRef]

33. Li, C.; Zhang, L.; Gao, Y.; Li, A. Facile synthesis of nano ZnO/ZnS modified biochar by directly pyrolyzing of zinc contaminated corn stover for $\mathrm{Pb}(\mathrm{II}), \mathrm{Cu}(\mathrm{II})$ and $\mathrm{Cr}(\mathrm{VI})$ removals. Waste Manag. 2018, 79, 625-637. [CrossRef] [PubMed]

34. Zhang, J.; Chen, S.; Zhang, H.; Wang, X. Removal behaviors and mechanisms of hexavalent chromium from aqueous solution by cephalosporin residue and derived chars. Bioresour. Technol. 2017, 238, 484-491. [CrossRef] [PubMed]

35. Hong, W.; Tian, Z.; Ling, J.; Luo, W.; Wei, Z.; Li, S.; Jing, C.; Wei, W. Highly efficient adsorption of Cr(VI) from aqueous solution by $\mathrm{Fe}^{3+}$ impregnated biochar. J. Dispers. Sci. Technol. 2017, 38, 815-825.

36. Ping, Y.; Guo, D.; Chen, Z.; Cui, B.; Bo, X.; Liu, S.; Hu, M. Removal of Cr(VI) from aqueous solution using magnetic biochar synthesized by a single step method. J. Dispers. Sci. Technol. 2016, 38, 1665-1674.

(C) 2020 by the authors. Licensee MDPI, Basel, Switzerland. This article is an open access article distributed under the terms and conditions of the Creative Commons Attribution (CC BY) license (http://creativecommons.org/licenses/by/4.0/). 